\title{
Conservation at the individual level: successful rehabilitation and post-release monitoring of an Italian wolf (Canis lupus italicus) injured in a car accident
}

\author{
Carmela Musto $^{1 \#}$, Romolo Caniglia ${ }^{2 \#}$, Elena Fabbri ${ }^{2}$, Marco Galaverni ${ }^{3}$, Noemi Romagnoli ${ }^{1}$, \\ Stefania Pinna ${ }^{1}$, Elisa Berti ${ }^{4}$, Marzia Naldi ${ }^{4}$, Emanuela Bologna ${ }^{4}$, Luigi Molinari ${ }^{5}$, \\ Sara Del Magno ${ }^{1}$, and Mauro Delogu ${ }^{1 *}$ \\ ${ }^{1}$ Department of Veterinary Medical Sciences, Alma Mater Studiorum-University of Bologna, Bologna, Italy \\ ${ }^{2}$ Area per la Genetica della Conservazione (BIO-CGE), Istituto Superiore per la Protezione e Ricerca Ambientale \\ (ISPRA), Bologna, Italy \\ ${ }^{3}$ Area Conservazione, WWF Italia, Roma, Italy \\ ${ }^{4}$ Centro Tutela e Ricerca Fauna Esotica e Selvatica-Monte Adone, Bologna, Italy \\ ${ }^{5}$ Wolf Apennine Center, Parco Nazionale dell'Appennino Tosco-Emiliano, Reggio Emilia, Italy
}

MUSTO, C., R. CANiglia, E. FABBRI, M. GALAVERNi, N. ROMAGNOLI, S. PINNA, E. BERTI, M. NALDI, E. BOLOGNA, L. MOLINARI, S. DEL MAGNO, M. DELOGU: Conservation at the individual level: successful rehabilitation and post-release monitoring of an Italian wolf (Canis lupus italicus) injured in a car accident. Vet. arhiv 90, 205-212, 2020.

\section{ABSTRACT}

This case report describes the rescue of an eight-month-old male Italian wolf (Canis lupus italicus), the victim of a car accident that caused it a pulmonary contusion, a fracture of the shaft of right femur, and a metaphyseal fracture of the left stifle. A lateral surgical approach was performed to treat the animal's multiple contusions and fractures. Afterwards the wolf was transferred to a wild animal recovery center for its rehabilitation, where it fully recovered. After 35 days in captivity the wolf was thus released into the supposed home-range of its original pack, and its movements were monitored by a GPS satellite collar. The collar worked correctly for 479 days. During that period the collar acquired a total of 1202 locations, indicating that the wolf had traveled at least $1590 \mathrm{~km}$, with an average monthly distance $( \pm \mathrm{SD})$ of $102 \pm 40 \mathrm{~km}$, exploring an overall area of about $270 \mathrm{~km}^{2}$. During the first 10 days after its release, the wolf remained in the area of its supposed native pack, whereas at about the age of 10 months the wolf began to make wide extraterritorial movements. The wolf's last localization was acquired on $13^{\text {th }}$ May 2018, about 17 months after its release, at a linear distance of about $65 \mathrm{~km}$ from the release site. These preliminary data showed that the wolf was alive and travelled long distances after its release, and demonstrates how a multidisciplinary management approach can support the recovery and successful release into nature of a rescued wild animal belonging to a flagship species with a notable ecological role, such as the Italian wolf.

Key words: Italian wolf; conservation; wildlife rehabilitation; orthopaedic surgery; radio-tracking

\footnotetext{
\# Carmela Musto and Romolo Caniglia contributed equally to this work
}

\footnotetext{
*Corresponding author:

Mauro Delogu, Department of Veterinary Medical Sciences, Alma Mater Studiorum-University of Bologna, Via Tolara di Sopra 50, 40064 Ozzano dell’Emilia, Bologna, Italy, E-mail: mauro.delogu@unibo.it
} 


\section{Introduction}

After centuries of severe population decline, mainly due to human maltreatment and loss of habitat, the wolf (Canis lupus) population is now expanding again in many European countries (CHAPRON et al., 2014). In particular, Italian wolves (Canis l. italicus, ALTOBELLO, 1921), having experienced a historical demographic scenario characterized by protracted isolation south of the Alps, and recurrent bottlenecks that made them sharply genetically differentiated from any other wolf population, represent an unquestionable example of recent conservational success (MONTANA et al., 2017). Indeed, after being close to extinction, during the 1980 s, Italian wolves started a natural re-colonization in parts of their historical range along the Apennine, reaching the western Alps, France and Switzerland (ZIMEN and BOITANI, 1975; FABBRI et al., 2007), and currently include at least 320 wolf packs which approximately correspond to at least $1500( \pm 300)$ wolves (GALAVERNI et al., 2016). The ecological plasticity of the species, indeed, helped it to face and exploit the recent environmental transformations of our landscapes successfully (MILANESI et al., 2015). However, the return of this predator to both remote and semi-urbanized areas may cause social conflicts with local communities, since its presence is still perceived as a potential threat to human activities and safety (LINNELL and BOITANI, 2012; GLIKMAN et al., 2012).

For these reasons, despite this favorable demographic trend, the Italian wolf population remains locally threatened by excessive poaching and accidental killings, especially due to road mortality, which may remove more than $20 \%$ of the individuals from the population every year (GALAVERNI et al., 2016). The subspecies, therefore, is still strictly protected under the Bern Convention (Appendix II) and Habitats Directive (Annex II and IV), is included in the CITES Appendix, and is currently classified in the IUCN Red Lists as "Vulnerable" for the Alpine sub-population and "Near Threatened" for the Peninsular sub-population.

The release into the wild of injured animals rehabilitated in captivity often raises scientific and ethical questions (MULLINEAUX, 2014). Indeed, rescued animals might have low survival probability due to possible habituation resulting from human contact (MOORE et al. 2007; GUY et al. 2013), and they could spread diseases or be involved in human-wildlife conflicts (MULLINEAUX, 2014). However, releases may also play an active role in conservation by recovering and returning individuals to local populations of endangered species (SARAN et al., 2011).Therefore, their possible release should be carefully evaluated (RIO-MAIOR et al., 2016). In this study, we describe how a multidisciplinary approach may favor the recovery of an injured Italian wolf and its successful release into nature.

\section{Case report}

On $13^{\text {th }}$ December 2016, a male Italian wolf was found seriously injured after a car collision on a provincial road in the northern Italian Apennine (Ozzano dell' Emilia, Bologna Province; N 44.3620554, E 11.418489), an area where a wellknown wolf pack lives (CANIGLIA et al., 2014).

The animal was urgently brought to the Veterinary Hospital of the University of Bologna to assess its health condition and to receive any necessary medical care.

Triage and clinical examination highlighted that it was possibly affected by a pulmonary contusion and the inability to stand up. Therefore, analgesia (Methadone $0.2 \mathrm{mg} / \mathrm{kg} \mathrm{i} / \mathrm{v}$ ) and fluid therapy were administered through the intravenous administration of a fluid bolus (Ringer Lactate $5 \mathrm{~mL} / \mathrm{kg}$ ). During the stabilization phase, an abdominal ultrasound check (Focused Assessment with Sonography for Trauma-FAST) showed no evidence of free fluid or air in the abdomen, while a pulmonary contusion at the thoracic level was observed on T-FAST. Open wounds were detected on the left knee joint and both femurs. Therefore antibacterial therapy was given (Cefazolin $30 \mathrm{mg} / \mathrm{kg}$ TID i/v) and the injuries were carefully irrigated with physiological solution and diluted povi-iodine.

An orthopedic examination was indicative of bilateral femoral fractures that were confirmed by the radiographic examination, showing a short oblique proximal third diaphyseal fracture of the 
right femur and a metaphyseal fracture (SalterHarris type I) of the left femur.

Additionally, one sample of $1 \mathrm{~mL}$ of blood was taken, placed into two EDTA tubes $(0.5 \mathrm{~mL}$ each) and immediately sent to the Laboratory of the Unit for Conservation Genetics at ISPRA (Italian Institute for Environmental Protection and Research, Ozzano dell'Emilia, Italy) to perform molecular analyses. Molecular analyses were carried out in order to: i) verify the population of origin of the animal and exclude, before its release, the possible presence of a marked dog ancestry in its genome; ii) compare its genetic profile with the large database of Italian wolf genotypes (the ISPRA Canis database; FABBRI et al., 2018) for possible matches or kinship relationships with animals previously genotyped during a local monitoring project (CANIGLIA et al., 2014).

DNA was extracted using a QIAGEN DNA Easy Tissue extraction kit (Qiagen Inc, Hilden, Germany), PCR-amplified, then sequenced at 500 bp of the hypervariable domain of the mtDNA control-region (diagnostic for the Italian wolf population) and genotyped through a multiple-tube approach at 39 autosomal microsatellites (which differentiates well between wolves, dogs and their first two-three generation hybrids) and at a deletion at the b-defensin CBD103 gene causing a melanistic coat pattern (ANDERSON et al., 2009; CANIGLIA et al., 2014; RANDI et al., 2014). Extraction, amplification and post-amplification procedures were carried out in three separate rooms, restricted to low-template DNA samples.

Genetic and Bayesian (FABBRI et al., 2018) analyses confirmed that the animal was a pure male Italian wolf, never sampled before and with no apparent kinship relationships with the animals previously genotyped in the same area (CANIGLIA et al., 2014).

The animal was morphologically classified as a juvenile and, on the basis of tooth wear (GIPSON et al., 2000) and on the local birth time of wolves in central Italy, usually at the beginning of May (BOSCAGLI, 1985), its age was estimated to be approximately 8 months.
Before undergoing surgery, the wolf was tranquillized with Acepromazine $(20 \mu \mathrm{g} / \mathrm{kg}$ intramuscularly) and about twenty minutes later was sedated with Dexmedetomidine $(2 \mu \mathrm{g} / \mathrm{kg}$ intravenous $\mathrm{i} / \mathrm{v})$. Then anesthesia was inducted with Propofol (2 mg/kg i/v) and Midazolam $(0.1 \mathrm{mg} / \mathrm{kg}$ $\mathrm{i} / \mathrm{v})$. Once unconscious, the trachea of the wolf was intubated and anesthesia was maintained with 1.4 $\mathrm{MAC}=3 \%(+/-0.2 \%)$ end-tidal (Et) isoflurane in oxygen and air (FiO2 0.50). During the entire surgical procedure, analgesia was maintained with a continuous infusion rate of Fentanyl (range 5-10 $\mu \mathrm{g} / \mathrm{kg} / \mathrm{h}$ ) and the wolf was artificially ventilated using a semi-closed circle system. Both hind limbs were shaved and scrubbed for surgery.

A lateral approach (PIERMATTEI and JOHNSON, 2004a) was used to reduce the fracture on the shaft of the right femur, and the subsequent osteosynthesis was executed with a plate and rod construct, using a $3.5 \mathrm{~mm}$ dynamic compression plate and a $3 \mathrm{~mm}$ intramedullary Steinmann pin (DECAMP et al., 2016). A lateral approach was also used on the left stifle (PIERMATTEI and JOHNSON, 2004b) and the metaphyseal fracture was reduced using Rush-like pinning and crosspinning (DECAMP et al., 2016). After the surgery, the Monte Adone Rescue Centre operators assisted the wolf, still sedated, and transferred it to the Center's headquarters within the wolf hosting area, for its rehabilitation. In addition to clinical assessment, in order to minimize any contact with humans, the wolf was managed daily by a single operator and monitored through surveillance cameras. The day after the surgery the wolf spontaneously started eating again; both eggs and wild ungulate meat were provided, integrated with Rexo rubia (Lehning Laboratoires).

At the time of admission antibiotic therapy with Ceftriaxone $(20 \mathrm{mg} / \mathrm{kg}$ SID i/v for 4 days and SC for 8 days and Clindamycin $11 \mathrm{mg} / \mathrm{Kg}$ SID i/v for 4 days and SC for 21 days) and pain therapy with Tramadol (3 mg/Kg SC TID for 2 days then BID for 4 days, then SID for 2 days) were prescribed. During the antibiotic treatments, lactic ferments (Florentero $4 \mathrm{cp} /$ day) were administered with meals. Additionally, as it currently represents an acceptable and effective approach in modern integrative 
veterinary medicine (HIELM-BJÖRKMAN et al., 2009), homotoxicological therapy was applied (WRONSKI et al., 2018) and a cocktail of Arnica compositum heel, Kalmia compositum heel, Apis hommacord heel, Solanum compositum heel, Aconitum heel, Galium heel, Cuprum heel $(1 \mathrm{~mL} / \mathrm{i} / \mathrm{v}$ for $5 \mathrm{~g}$ TID than SC for 20 days SID) was given to the patient. Intravenous maintenance fluid therapy based on rehydrating Electrolyte III $(2 \mathrm{mg} / \mathrm{kg} / \mathrm{h})$ was also administered, supplemented with Metabolase solution for injection $(2 \mathrm{~mL} / \mathrm{kg} /$ day) for 5 days.

After the first few days of intensive treatment, the animal gradually began to get up, albeit without placing weight on the right hind limb, which still looked inflamed and painful. Acupuncture sessions, without sedating the animal, were carried out 13,22 and 25 days after the surgery, and integrated with the homotoxicological therapy with Lymphomyosot heel. In addition, allopathic therapy with Dexamethasone $(0.1 \mathrm{mg} / \mathrm{kg}$ SC SID) was added for 2 days, followed by Robenacoxib ( $2 \mathrm{mg} / \mathrm{kg}$ SC SID for 7 days); the swelling of the right hind limb quickly faded and the wolf started using it. To avoid any kind of habituation during the hospitalization period, direct contact of the animal with humans necessary for its care was minimized. During medical treatment and acupuncture the animal was managed by only one operator and one veterinarian in a very isolated space near the forest, covering the wolf's head with a blanket and not using a muzzle or sedation. The veterinary left the box and returned within 20 minutes to remove the needles.

The wolf accepted the captivity without showing stereotypical behaviors or attempts to escape. Twenty days after the surgery it again stopped leaning on its right hind limb. A subsequent radiographic exam showed a longitudinal fracture of the distal femoral stump, along the distal 5 plate's screws. An ultrasound exam was also performed to evaluate the muscular state of the limb; the exam showed poor circulation as well as a fibrosis of the deep muscular bundles, and extensive mineralization of the distal tendon heads and the muscular body. Daily mesotherapy, namely the administration of drugs (or natural compounds) through multiple intradermal or subcutaneous injections in a mixture of small amounts (SIVAGNANAM, 2010), was applied to perform medical local treatment (CHEN et al., 2018). The wolf gradually began to lean on the right hind limb again and to be more active and reactive. The last radiographic exam, performed 30 days after surgery, showed a moderate amount of bone deposition along the longitudinal fracture of the distal femoral stump. On $19^{\text {th }}$ January 2017, 35 days after surgery, the wolf was subjected to a final ultrasound exam of the right hind limb, which showed significant improvement over the previously reported situation. Therefore, in agreement with the national authorities (the Italian Ministry of the Environment, after a positive assessment by the ISPRA), the animal was released back near the site of its discovery. The wolf was fitted with a satellite collar (Pro Light model, Vectronic Aerospace GmBh, Berlin, Germany) supplied by the Appennino Tosco-Emiliano National Park. The collar was set to acquire 1 location every 5 hours during the first month (from $19^{\text {th }}$ January 2017 until $18^{\text {th }}$ February 2017), then every 10 hours (from $18^{\text {th }}$ February 2017 onwards) and the Global System for Mobile Communications (GSM) allowed the collection of data about the position of the animal.

The collar worked correctly until $13^{\text {th }}$ May 2018, after a telemetry monitoring period of 479 days. During this period, the collar acquired a total of 1202 locations of the 1316 programmed, with an acquisition rate of $91 \%$. Most of the localizations $(98 \%)$ were found to have high precision (3D). The distance traveled by the wolf was calculated through the combination of successive localizations. In total, the wolf traveled $1590 \mathrm{~km}$, with a monthly average distance $( \pm$ SD) traveled of $102 \pm 40 \mathrm{~km}$. During the first 10 days after release, the wolf remained in the area of its supposed native pack, which had been identified by camera traps, wolf-howling and direct observations that confirmed the presence of a rendezvous site with at least 6 pups. After the release, an operator observed the wolf inside the rendezvous of the hypothesized pack. From March 2017, at the age of about 10 months, the wolf began extraterritorial movements (up to a $20-\mathrm{km}$ linear distance from the rendezvous area). 
For about 6 months (between June and November 2017), the wolf frequented an area of $167 \mathrm{~km}^{2}(100 \% \mathrm{MCP})$ about $30 \mathrm{~km}$ south of the hypothetical territory of its native pack (Polygon A-Fig. 1). From February 2017 to May 2018, the wolf began to explore an area of about $270 \mathrm{~km}^{2}$ $(100 \% \mathrm{MCP})$, located about $30 \mathrm{~km}$ south of the first one (Polygon B-Fig. 1). The last location of the wolf was acquired on $13^{\text {th }}$ May 2018 at a linear distance of about $65 \mathrm{~km}$ from the release site, about 17 months earlier (January 2017).

Meanwhile, the road section where the car accident occurred was equipped with a combination of passive optic and acoustic devices for wildlifevehicle collision avoidance, in order to mitigate the risk of death or injuries fother members in the local pack in the future.

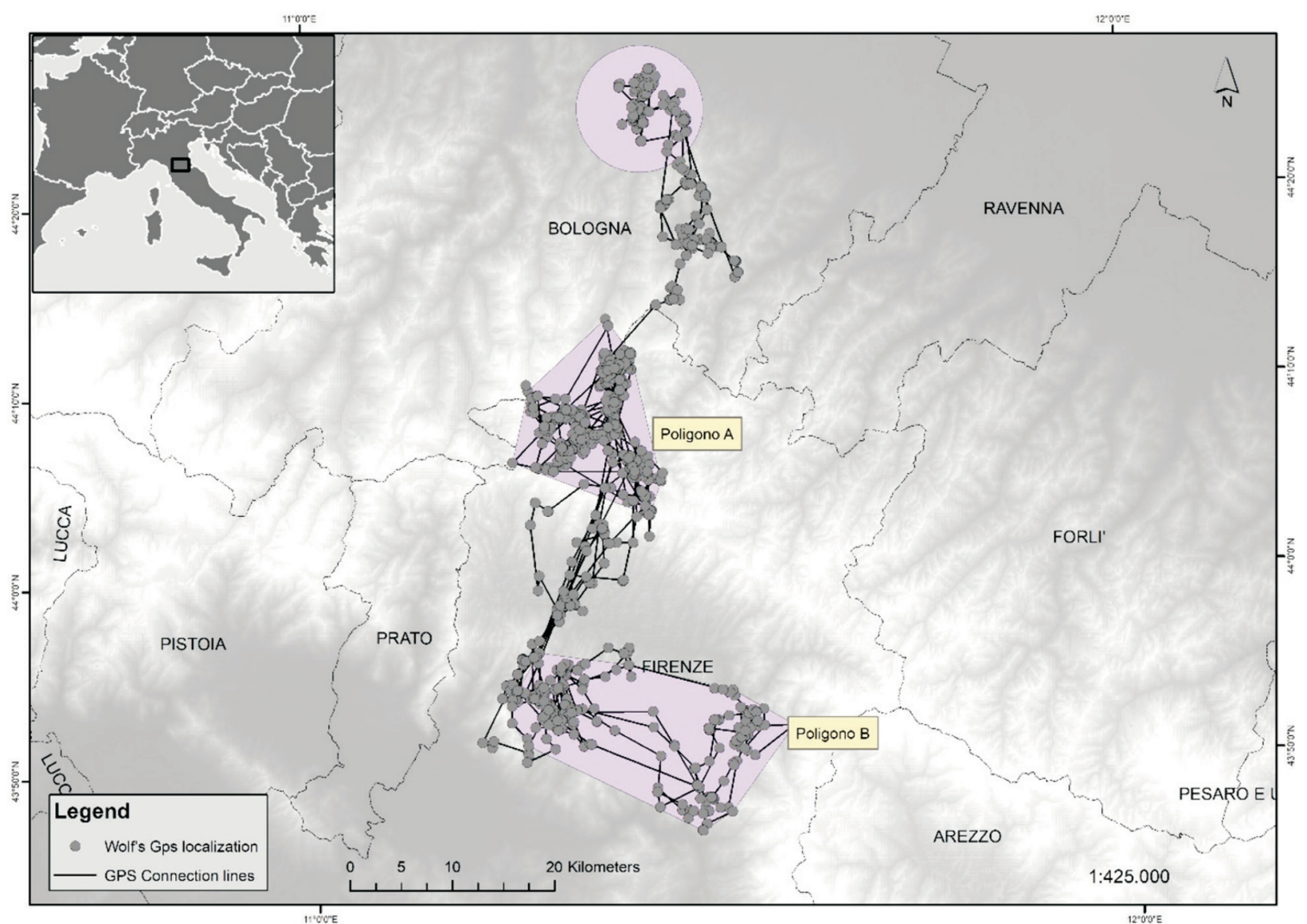

Fig. 1. Map of the successive localizations of the released Italian wolf acquired from the satellite radio collar applied, throughout the whole telemetry monitoring period (19 $9^{\text {th }}$ January 2017- $13^{\text {th }}$ May 2018). The circle represents the hypothetical territorial area of the native pack of the rescue wolf. Polygon A represents the area where the released wolf lived from June to November 2017 whereas polygon B represents the area frequented by the wolf between February 2017 and May 2018.

\section{Discussion}

Although a number of studies have been carried out to investigate the ecological role of wolves in the ecosystem equilibria, and the conservation status of most European wolf populations, to our knowledge, the post-release behavior and the effects of captivity on rescued wolves has been only seldom addressed (MECH and BOITANI, 2003; RIO-MAIOR et al., 2016). Overall, the few studies dealing with these topics suggest that the release of rehabilitated wolves might contribute to the conservation of local populations by the return of rescued individuals into their natal resident 
packs, while maintaining their original social role (RIO-MAIOR et al., 2016). However, the few cases about the post-release behavior of rehabilitated wolves reported in the current scientific literature were mainly focused on animals without severe traumatic injuries. Indeed, only one study described the rehabilitation and successive release of two severely injured wolves in Northwest Portugal (RIO-MAIOR et al., 2016) and in only one other, the activities of a rehabilitated and released wolf were closely monitored over a long post release period (CIUCCI et al., 2009).

In Italy, despite its current re-expansion and increasing abundance, the wolf is still considered a conservational priority because of its persisting high mortality, especially in human-dominated landscapes, and its subspecies uniqueness (CHAPRON et al., 2014; GALAVERNI et al., 2016; MONTANA et al., 2017). In this context, the successful rescue and release of an individual could reinforce the local wolf population viability, by returning to its resident pack a young individual which might later become a helper or a reproductive pack member. Additionally, to evaluate the actual success of the release operation, we documented the post-release survival and movement patterns of the rehabilitated wolf using a GPS satellite collar. Overall, our results suggest that the deep traumatic injuries suffered by the wolf, and the 35 days spent in captivity for its rehabilitation appeared not to have impaired its ability to move across its territory, even though the wolf limited its movements to a relatively restricted area in the initial period after its release. However, a comparable pattern was reported by CIUCCI et al. (2009) for a rehabilitated wolf that remained within a circumscribed area for about 2 months after its release, before embarking on long-distance dispersal movements. This behavioral pattern might indicate an initial recovery phase of about 1-2 months after the release, whose duration might depend on the extent of the injury and the length of the rehabilitation period, but also on the release season and on the young age of the wolf. Its age may have positively influenced its quick post-release integration into the original pack, since young individuals should be more easily accepted by pack members (SCHULTZ et al., 1999). Pack members usually show hostility to external adult members, which could lead to aggression, encouraging released wolves to remain transient (MECH and BOITANI, 2003), but in this case the wolf pup was released in the area from which it originated, and into its natal pack.

This study demonstrates how a multidisciplinary management approach, involving the expertise of veterinarians, geneticists, wildlife biologists and the personnel of wildlife rescue centers, can favor the recovery and the successful release into nature of a rescued wild animal, which is crucial especially when it belongs to a flagship species with a high ecological role, such as wolves.

We believe that this successful example could be replicated in other contexts and species/subspecies with a high conservational value.

\section{Acknowledgments}

We would particularly like to thank Paul Montgomery for the revision of the English style, Maria Luisa Zanni (Regione Emilia Romagna), the staff of the Department of Veterinary Medical Sciences - University of Bologna, the staff of the Wolf Apennine Center (in particular Willy Reggioni), the collaborators of the Monte Adone Rescue Centre (Donatella Zambelli, Offer Zeira, Daniele Zahirpour, Caterina Maestrami, Mario Pischedda, Renato Ceccherelli, Gabriela Attanasi), Marco Antonelli for setting up devices for vehicle collision avoidance in the accident location, Massimo Colombari and all the volunteers who contributed to the recovery of the wolf.

\section{References}

ANDERSON, T. M., B. M. VONHOLDT, S. I. CANDILLE, M. MUSIANI, C. GRECO, D. R. STAHLER, D. W. SMITH, B. PADHUKASAHASRAM, E. RANDI, J. A. LEONARD, C. D. BUSTAMANTE, E. A. OSTRANDER, H. TANG, R. K. WAYNE, G. S. BARSH (2009): Molecular and evolutionary history of melanism in North American gray wolves. Science 323, 1339-1343.

DOI: $10.1126 /$ science. 1165448

ALtoBello, G. (1921): Fauna of Abruzzo and Molise. In: Mammals IV, Carnivores. Colitti, Campobasso, pp. 38-45 (in Italian)."

BOSCAGLI, G. (1985): Distribution and current number of wolves in Italy. Natura 76, 77-93 (in Italian).

CANIGLIA, R., E. FABBRI, M. GALAVERNI, P. MILANESI, E. RANDI (2014): Non-invasive sampling and genetic variability, pack structure, and dynamics in an expanding wolf population. J. Mammal. 95, 41-59.

DOI: 10.1644/13-mamm-a-039 
CHAPRON, G, P. KACZENSKY, J. D. C. LINNEL, M. VON ARZ, D. HUBER, H. ANDRÉN, J. V. LÓPEZBAO, M. ADAMEC, F. ÁlVARES, O. ANDERS, L. BALČIAUSKAS, V. BALYS, P. BEDÖ, F. BEGO, J. C. BLANCO, U. BREITENMOSER, H. BRØSETH, L. BUFKA, R. BUNIKYTE, P. CIUCCI, A. DUTSOV, T. ENGLEDER, C. FUXJÄGER, C. GROFF, K. HOLMALA, B. HOXHA, Y. ILIOPOULOS, O. IONESCU, J. JEREMIĆ, K. JERINA, G. KLUTH, F. KNAUER, I. KOJOLA, I. KOS, M. KROFEL, J. KUBALA, S. KUNOVAC, J. KUSAK, M. KUTAL, O. LIBERG, A. MAJIĆ, P. MÄNNIL, R. MANZ, E. MARBOUTIN, F. MARUCCO, D. MELOVSKI, K. MERSINI, Y. MERTZANIS, R. W. MYSŁAJEK, S. NOWAK, J. ODDEN, J. OZOLINS, G. PALOMERO, M. PAUNOVIĆ, J. PERSSON, H. POTOČNIK, P. Y. QUENETTE, G. RAUER, I. REINHARDT, R. RIGG, A. RYSER, V. SALVATORI, T. SKRBINŠEK, A. STOJANOV, J. E. SWENSON, L. SZEMETHY, A. TRAJÇE, E. TSINGARSKA-SEDEFCHEVA, M. VÁŇA, R. VEEROJA, P. WABAKKEN, M. WÖLFL, S. WÖLFL, F. ZIMMERMANN, D. ZLATANOVA, L. BOITANI (2014): Recovery of large carnivores in Europe's modern human-dominated landscapes. Science 346, 1517-1519.

DOI: $10.1126 /$ science. 1257553

CHEN, L., D. LI, J. ZHONG, B. QIU, X. WU (2018): Therapeutic effectiveness and safety of mesotherapy in patients with osteoarthritis of the knee. Evid-Based Compl. Alt. 1-6.

CIUCCI, P., W. REGGIONI, L. MAIORANO, L. BOITANI (2009): Long-distance dispersal of a rescued wolf from the Northern Apennines to the Western Alps. J. Wildlife Manage. 73, 1300-1306.

DOI: $10.2193 / 2008-510$

DECAMP, C. E., S. A. JOHNSTON, L. M. DÉJARDIN, S. L. SCHAEFER (2016): Fractures of the femur and patella. In: Brinker, Piermattei and Flo's Handbook of Small Animal Orthopaedics and Fracture Repair. (DeCamp, C. E., S. A. Johnston, L. M. Déjardin, S. L. Schaefer, Eds.). $5^{\text {th }}$ ed., Elsevier, St. Louis, pp. 518-596.

DOI: 10.1016/b978-1-4377-2364-9.00026-4

FABBRI, E., C. MIQUEL, V. LUCCHINI, A. SANTINI, R. CANIGLIA, C. DUCHAMP, J. M. WEBER, B. LEQUETTE, F. MARUCCO, L. BOITANI, L. FUMAGALLI, P. TABERLET, E. RANDI (2007): From the Apennines to the Alps: colonization genetics of the naturally expanding Italian wolf (Canis lupus) population. Mol. Ecol. 16, 1661-1671.

DOI: 10.1111/j.1365-294x.2007.03262.x

FABBRI, E., E. VELLI, F. D’AMICO, M. GALAVERNI, L. MASTROGIUSEPPE, F. MATTUCCI, R. CANIGLIA (2018): From predation to management: monitoring wolf distribution and understanding depredation patterns from attacks on livestock. Hystrix 29, 101-110.

GALAVERNI, M, R. CANIGLIA, E. FABBRI, P. MILANESI, E. RANDI (2016): One, no one, or one hundred thousand: how many wolves are there currently in Italy?. Mammal Res. 61, 13-24.

DOI: $10.1007 / \mathrm{s} 13364-015-0247-8$

GIPSON, P. S., W. B. BALLARD, R. M. NOWAK, D. MECH (2000): Accuracy and precision of estimating age of gray wolves by tooth wear. J. Wildlife Manage. 64, 752-758.

DOI: $10.2307 / 3802745$

GLIKMAN, J. A., J. J. VASKE, A. J. BATH, P. CIUCCI, L. BOITANI (2012): Residents' support for wolf and bear conservation: the moderating influence of knowledge. Eur. J. Wildl. Res. 58, 295-302.

DOI: $10.1007 / \mathrm{s} 10344-011-0579-\mathrm{X}$

GUY, A. J., D. CURNOE, P. B. BANKS (2013): A survey of current mammal rehabilitation and release practices. Biodivers. Conserv. 22, 825-837.

DOI: $10.1007 / \mathrm{s} 10531-013-0452-1$

HIELM-BJÖRKMAN, A., R. M. TULAMO, H. SALONEN, M. RAEKALLIO (2009): Evaluating complementary therapies for canine osteoarthritis-Part II: a homeopathic combination preparation (Zeel). Evid-Based Compl. Alt. 6, 465-71.

DOI: $10.1093 /$ ecam/nem143

LINNELL, J. D. C., L. BOITANI (2012): Building biological realism into wolf management policy: the development of the population approach in Europe. Hystrix 23, 80-91.

MECH, L. D., L. BOITANI (2003): Wolf social ecology. In: Wolves: behavior, ecology, and conservation (Mech, L. D., L. Boitani, Eds). University of Chicago Press, Chicago, Illinois, USA, pp. 1-34.

DOI: $10.7208 /$ chicago/9780226516981.001.0001

MILANESI, P., R. CANIGLIA, E. FABBRI, M. GALAVERNI, A. MERIGGI, E. RANDI (2015): Non-invasive genetic sampling to predict wolf distribution and habitat suitability in the Northern Italian Apennines: implications for livestock depredation risk. Eur. J. Wildl. Res. 61, 681-689. DOI: $10.1007 /$ s10344-015-0942-4

MONTANA, L., R. CANIGLIA, M. GALAVERNI, E. FABBRI, A. AHMED, B. Č. BOLFÍKOVÁ, S. D. CZARNOMSKA, A. GALOV, R. GODINHO, M. HINDRIKSON, P. HULVA, B. JĘDRZEJEWSKA, M. JELENČIČ, M. KUTAL, U. SAARMA, T. SKRBINŠEK, E. RANDI (2017): Combining phylogenetic and demographic inferences to assess the origin of the genetic diversity in an isolated wolf population. PLoS ONE 12, 1-19.

DOI: 10.1371/journal.pone.0176560

MOORE, M., G. EARLY, K. TOUHEY, S. BARCO, F. GULLAND, R. WELLS (2007): Rehabilitation and release of marine mammals in the United States: risks and benefits. Mar. Mammal Sci. 23, 731-750.

DOI: $10.1111 /$ j.1748-7692.2007.00146.x

MULLINEAUX, E. (2014): Veterinary treatment and rehabilitation of indigenous wildlife. J. Small Anim. Pract. 55, 293-300.

DOI: $10.1111 /$ jsap. 12213 
C. Musto et al.: Conservation at the individual level: successful rehabilitation and post-release monitoring of an Italian wolf (Canis lupus italicus) injured in a car accident

PIERMATTEI, D. L., K. A. JOHNSON (2004a): Approach to the shaft of the femur. In: An Atlas of Surgical Approaches to the Bones and Joints of the Dog and Cat. (Piermattei, D. L., K. A. Johnson, Eds.). Saunders, Philadelphia, pp. 336-337. DOI: $10.1016 / \mathrm{b} 978-0-7216-8707-0.50004-\mathrm{x}$

PIERMATTEI, D. L., K. A. JOHNSON (2004b): Approach to the distal femur and stifle joint through a lateral approach. In: An Atlas of Surgical Approaches to the Bones and Joints of the Dog and Cat. (Piermattei, D. L., K. A. Johnson, Eds) Saunders, Philadelphia, pp. 338-341.

DOI: $10.1016 / \mathrm{b} 978-0-7216-8707-0.50007-5$

RANDI, E., P. HULVA, E. FABBRI, M. GALAVERNI, A. GALOV, J. KUSAK, D. BIGI, B. Č. BOLFÍKOVÁ, M. SMETANOVÁ, R. CANIGLIA (2014): Multilocus detection of wolf $\times$ dog hybridization in Italy, and guidelines for marker selection. PLoS One 9, 1-13.

DOI: 10.1371/journal.pone.0086409

RIO-MAIOR, H., P. BEJA, M. NAKAMURA, N. SANTOS, R. BRANDAO, R. SARGO, I. DIAS, F. SILVA, F. ALVARES (2016): Wolf rehabilitation and post-release monitoring of two wolves with severe injuries. J. Wildlife Manage. 80, 729-735.

DOI: 10.1002/jwmg.1055
SARAN, K. A., G. PARKER, R. PARKER, C. R. DICKMAN (2011): Rehabilitation as a conservation tool: a case study using the common wombat. Pac. Conserv. Biol. 17, 310-319. DOI: $10.1071 /$ pc110310

SCHULTZ, R. N., A. P. WYDEVEN, J. M. STEWART (1999): Acceptance of a gray wolf, Canis lupus, pup by its natal pack after 53 days in captivity. Can. Field Nat. 113, 509511.

SIVAGNANAM, G. (2010): Mesotherapy - The french connection. J. Pharmacol. Pharmacother. 1, 4-8.

ZIMEN, E., L. BOITANI (1975): Number and distribution of wolves in Italy. Z. Säugetierkunde 40, 102-112.

WRONSKI, S., J. DANNENMAIER, S. SCHILD, O. MACKE, L. MÜLLER, Y. BURMEISTER, B. SEILHEIMER, M. MÜLLER (2018): Engystol reduces onset of experimental respiratory syncytial virus-induced respiratory inflammation in mice by modulating macrophage phagocytic capacity. PLoS One 13, 1-13.

DOI: 10.1371/journal.pone.0195822

MUSTO, C., R. CANiglia, E. FABBRI, M. GALAVERNi, N. ROMAGNOLI, S. PINNA, E. BERTI, M. NALDI, E. BOLOGNA, L. MOLINARI, S. DEL MAGNO, M. DELOGU: Očuvanje na individualnoj razini: uspješna rehabilitacija i praćenje talijanskog vuka (Canis lupus italicus) nastradalog na prometnici nakon puštanja na slobodu. Vet. arhiv 90, 205-212, 2020.

\section{SAŽETAK}

Ovaj prikaz slučaja opisuje spašavanje osmomjesečnog mužjaka talijanskog vuka (Canis lupus italicus) koji je bio žrtva naleta vozila s posljedičnim nagnječenjem pluća, prijelomom vrata desne bedrene kosti prijelomom u području metafize lijevoga koljena. Primijenjen je lateralni kirurški pristup kako bi se sanirala višestruka nagnječenja i prijelomi u životinje. Nakon toga je vuk prevezen u centar za oporavak divljih životinja gdje se potpuno oporavio. Nakon 35 dana u zatočeništvu vuk je pušten u okoliš nalik na njegov prirodni te je praćen preko GPS ogrlice. Ogrlica je ispravno radila 479 dana. Za to je vrijeme pokazala 1202 lokacije, upućujući na to da je vuk prešao $1590 \mathrm{~km}, \mathrm{u}$ prosjeku mjesečno $102 \pm 40 \mathrm{~km}( \pm \mathrm{SD})$, istražujući područje od $270 \mathrm{~km}^{2}$. Prvih 10 dana nakon oslobađanja vuk je ostao u području nalik na njegov prirodni okoliš, no u dobi od 10 mjeseci počeo je odlaziti na šire područje. Posljednja je njegova lokacija zabilježena 13. svibnja 2018., oko 17 mjeseci nakon puštanja, na zračnoj udaljenosti od oko 65 $\mathrm{km}$ od mjesta ispuštanja. Ovaj preliminarni podatak pokazuje da je vuk bio živ i prelazio velike udaljenosti nakon oslobađanja. Također pokazuje da multidisciplinarni pristup spašavanju može pospješiti oporavak i uspješno vraćanje u prirodu divljih životinja koje pripadaju vodećim vrstama s velikom ekološkom važnošću, kao što je talijanski vuk.

Ključne riječi: talijanski vuk; očuvanje; oporavak divljih životinja; ortopedski kirurški zahvat; radiopraćenje 